\title{
EVALUATION OF THE BIOLOGICAL NITROGEN FIXATION CONTRIBUTION IN SUGARCANE PLANTS ORIGINATED FROM SEEDS AND INOCULATED WITH NITROGEN-FIXING ENDOPHYTES
}

\author{
Erineudo de Lima Canuto ${ }^{1 *}$; André Luis Martinez de Oliveira ${ }^{1}$; Verônica Massena Reis ${ }^{2}$. José Ivo Baldani² \\ ${ }^{1}$ Universidade Federal Rural do Rio de Janeiro, Rio de Janeiro, RJ, Brasil. ${ }^{2}$ Embrapa Agrobiologia, Seropédica, RJ, Brasil.
}

This paper corresponds to an "extended abstract" selected for oral presentation in the $22^{\text {nd }}$ Brazilian Congress of Microbiology, held in Florianópolis, SC, Brazil, in November 17-20, 2003

\begin{abstract}
The inoculation technique with endophytic diazotrophic bacteria in sugarcane has been shown as an alternative practice to plant growth promotion. The aim of this work was to evaluate the biological nitrogen fixation (BNF) contribution by different strains of Herbaspirillum seropedicae and Gluconacetobacter diazotrophicus in sugarcane plant inoculated from seeds. The seeds were planted in pots filled with nonsterile soil, inoculated with the bacterial strains and grown 10 months outside of the greenhouse. The BNF contribution of the inoculated bacteria varied depending on the plant species used as a control. The highest BNF contribution as well as the highest populations of reisolated bacteria was observed with inoculation of $H$. seropedicae strains. The roots appeared to be the preferential tissues for the establishment of the inoculated species.
\end{abstract}

Key words: endophytic diazotrophic bacteria, sugarcane, biological nitrogen fixation, Herbaspirillum seropedicae, Gluconacetobacter diazotrophicus.

\section{INTRODUCTION}

Nitrogen balance studies showed contributions of the biological nitrogen fixation (BNF) around $60 \%$ for some sugarcane varieties grown in large concrete tank planted with material originated from sets (5). On the other hand, studies with micropropagated sugarcane plants grown in smaller pots showed that the inoculation of endophytic diazotrophic bacteria could contributed with up to $30 \%$ of the total $\mathrm{N}$ present in the plants (3). Endophytic diazotrophic bacteria inoculated in seed born sugarcane contributed significantly to increase the root system (2). In this work, the BNF contribution by different strains of endophytic diazotrophic bacteria was tested, envisaging a fast and accurate methodology to select plant growth promoting bacteria to be used in sugarcane crop.

\section{MATERIALS AND METHODS}

Five different strains from Diazotrophic Bacterial Collection (DBC) were used to inoculate seeds of sugarcane (Table 1). The bacterial strains were grown overnight in Dyg's liquid media, and approximately $10^{8}$ cells $\mathrm{mL}^{-1}$ were introduced directly over the sugarcane seeds (SP 701143 x Co 421 breeding cross), sown in the pots filled with $50 \mathrm{~kg}$ of unsterile soil (A horizon of an Ultisol). The experimental design utilized was randomized complete with 4 replicates. The plant species Sorghum bicolor and a Pennisetum hybrid were used as control plants to BNF quantification, using the $\delta^{15} \mathrm{~N}$-isotope analysis with the following formula:

$$
\% \mathrm{BNF}=100 \mathrm{x} \frac{\left(\delta^{15} \mathrm{~N} \text { control plant }-\delta^{15} \mathrm{~N} \text { test plant }\right)}{\left(\delta^{15} \mathrm{~N} \text { control plant }\right)}
$$
*Corresponding author. Mailing address: Ladeira da Meteorologia, 3, Ecologia. 23851-970, Seropédica, RJ. Tel.: (+5521) 2682-5049. E-mail:
ericanuto@hotmail.com 
Table 1. Bacterial strains used in this study.

\begin{tabular}{ccccc}
\hline Strain & Specie & DBC code & Isolation source & Origin \\
\hline 3R-2 & G. diazotrophicus & BR 11509 & RB 739359 roots & CNPAB/RJ \\
PAL5 & G. diazotrophicus & BR 11281 & Saccharum spp. roots & Alagoas \\
HRC54 & H. seropedicae & BR 11335 & CB 45-3 roots & CNPAB/RJ \\
HRC50 & H. seropedicae & BR 11380 & SP 701143 roots & CNPAB/RJ \\
HCC101 & H. seropedicae & BR 11510 & SP 701284 stems & CNPAB/RJ \\
\hline
\end{tabular}

The bacterial counting were carried out after 9 month using the Most Probable Number (MPN) technique, using the semisolid JNFb and LGI-Pcaldo media to reisolate the inoculated $H$. seropedicae and G. diazotrophicus, respectively. Statistical analysis was runned with the SisVar 4.3 variance analysis software.

\section{RESULTS}

The highest total dry matter was observed in plants inoculated with the HRC50, 3R-2 and HRC54 strains (Fig. 1). These values were significantly higher than that presented in uninoculated plants, but significantly lower than the total dry matter accumulated in nitrogen fertilised plants.

The highest bacteria population was also observed in the plants inoculated with strains of the Herbaspirillum genus (1.0 $10^{6}$ cell g-1 fresh tissue). In addition, the highest populations were related to the root tissues as compared to stem tissues for all the inoculated strains (Table 2). The only exception was 3R2 strain which presented higher population in the stem as compared to the root tissues. Endophytic bacteria of the genus Herbaspirillum were also observed in the uninoculated plants, but in lower numbers than the inoculated ones.

The BNF contribution to sugarcane plants varied accordingly to the plant species used as a control. The values

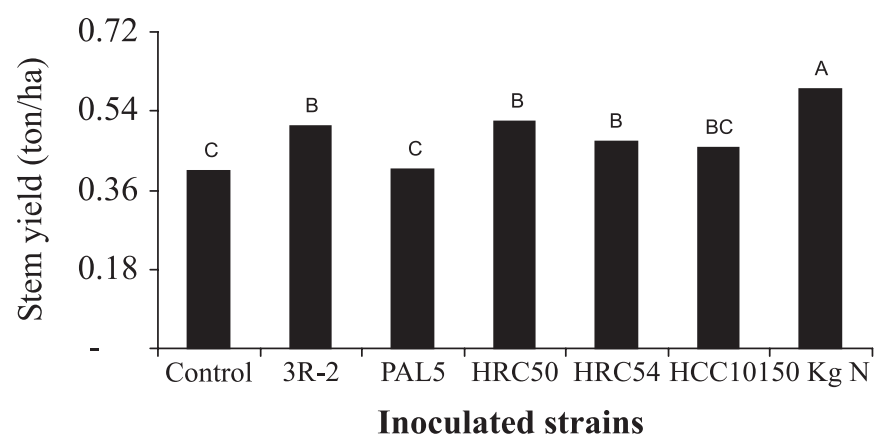

Figure 1. Total dry matter accumulated in sugarcane plants from seeds inoculated with endophytic diazotrophic bacteria. Same letters do not differ statistically by LSD test at $5 \%$ of confidence. Means of 4 pots. CV: $9.11 \%$. varied from 7.95 to $28.28 \%$ when the Pennisetum hybrid was used as a control (Table 3). A much higher BNF contribution (39.05 to 52.51\%) was observed using the S. bicolor. The highest BNF contribution was observed with the inoculation of the $H$. seropedicae HCC101, while the lowest efficient strain was the G. diazotrophicus PAL5.

Table 2. MPN counting of endophytic bacteria present in plant tissues evaluated after 9 months of growth in pots outside greenhouse. Means of 4 replicates.

\begin{tabular}{lccc}
\hline \multirow{2}{*}{ Strains } & Culture & \multicolumn{2}{c}{$\begin{array}{c}\text { Log of the n. of cells/g } \\
\text { fresh weight }\end{array}$} \\
\hline & media & Roots & Stems \\
\cline { 2 - 4 } Uninoculated & $\mathrm{JNFb}$ & $1.3210^{3}$ & $1.3410^{3}$ \\
Uninoculated + & $\mathrm{JNFb}$ & $3.6310^{3}$ & $9.7710^{2}$ \\
HRC54 & $\mathrm{JNFb}$ & $1.0010^{6}$ & $8.5110^{4}$ \\
HRC50 & $\mathrm{JNFb}$ & $9.3310^{5}$ & $7.0910^{4}$ \\
HCC101 & $\mathrm{JNFb}$ & $7.9410^{5}$ & $3.3810^{4}$ \\
PAL5 & LGI-Pcaldo & $6.4510^{4}$ & $2.8110^{4}$ \\
3R-2 & LGI-Pcaldo & $7.2410^{4}$ & $1.3810^{5}$ \\
\hline
\end{tabular}

Table 3. Evaluation of the nitrogen fixing endophytes contributions to sugarcane plants originated from seeds using the $\delta^{15} \mathrm{~N}$-isotope technique.

\begin{tabular}{lccc}
\hline \multirow{2}{*}{ Treatments } & $\delta^{\mathbf{1 5} \mathbf{N}}$ & \multicolumn{2}{c}{$\begin{array}{c}\text { BNF contribution } \\
(\% \text { of total N)* } \\
\text { Control plants }\end{array}$} \\
\cline { 3 - 4 } & & Pennisetum & S. bicolor \\
\hline Control & 1,823 & 7.95 & 39.05 \\
3R-2 & 1,770 & 10.61 & 40.80 \\
PAL5 & 1,820 & 8.08 & 39.13 \\
HRC50 & 1,718 & 13.26 & 42.56 \\
HRC54 & 1,478 & 25.38 & 50.59 \\
HCC101 & 1,420 & 28.28 & 52.51 \\
\hline
\end{tabular}

* Significant at LSD test with $95 \%$ of confidence, obtained by comparison of $\delta^{15} \mathrm{~N}$ values of inoculated plants with $\delta^{15} \mathrm{~N}$ values of control plants. 


\section{DISCUSSION}

In general, nitrogen fixing endophytic populations in grasses has been identified associated to roots (1). Our results also showed much higher population in the roots, suggesting that roots are the preferential sites for colonization and activity for such bacteria. In addition, the results showed that the BNF contribution varied with the endophytic bacteria strains inoculated and the plant used as a control to calculate the nitrogen derived from the nitrogen fixation. Studies on BNF contribution to sugarcane plants naturally grown in the field and evaluated with the same $\delta^{15} \mathrm{~N}$ technique also varied according to control plant used (4). The BNF contribution of the seed-borne inoculated sugarcane plants, calculated based on the Pennisetum $\delta^{15} \mathrm{~N}$ values, was quite similar to that observed for micropropagated sugarcane plants inoculated with a mixture of five diazotrophic bacteria species and measured with the ${ }^{15} \mathrm{~N}$-isotope dilution technique (3). Although it is still preliminary, the inoculation of sugarcane seeds with endophytic diazotrophic bacteria seems to be a good methodology to introduce selected strains envisaging growth promoting and nitrogen fixation in sugarcane plants during the initial steps of the breeding programs. Nevertheless, field grown experiments must be carried out to confirm these results.

\section{ACKNOWLEDGEMENTS}

The authors thank PRONEX II and PADCT III for financial support, and UFRuralRJ, Copersucar and Embrapa Agrobiologia for logistical supports.

\section{RESUMO}

\section{Avaliação da contribuição da fixação biológica de nitrogênio em cana-de-açúcar originada de sementes e inoculada com endófitos fixadores de nitrogênio}

A técnica de inoculação com bactérias diazotróficas endofíticas na cana-de-açúcar apresenta-se como uma prática alternativa para promover o crescimento vegetal menos dependente da adubação nitrogenada. Este trabalho teve como objetivo avaliar a contribuição da fixação biológica de nitrogênio (FBN) por diferentes estirpes de Herbaspirillum seropedicae e Gluconacetobacter diazotrophicus inoculadas em plantas de cana-de-açúcar originadas de semente. As sementes foram plantadas em vasos com solo não estéril, inoculadas com as diferentes bactérias e mantidas por 10 meses ao ar livre. As maiores contribuições da FBN ocorreram com a inoculação de estirpes Herbaspirillum seropedicae, e dependeram da espécie vegetal utilizada como testemunha. As raízes apresentaram-se como o órgão vegetal preferencial para o estabelecimento das espécies inoculadas.

Palavras-chave: bactérias diazotróficas endofíticas, cana-deaçúcar, fixação biológica de nitrogênio, Herbaspirillum seropedicae, Gluconacetobacter diazotrophicus.

\section{REFERENCES}

1. Döbereiner, J.; Baldani, V.L.D.; Reis, V.M. Endophytic occurrence of diazotrophic bacteria in non-leguminous crops. In: Fendrick, I. et al. (eds). Azospirillum VI and Related Microorganisms. SprigerVerlag, Berlim, 1995, p.3-14.

2. Goi, S.R.; Silva, R.A.D.A.; Baldani, V.L.D.; Baldani, J.I. Influência da inoculação de bactérias diazotróficas endofíticas na formação de pêlos radiculares de cana-de-açúcar. Resumo In: Fertbio 98. Interrelação Fertilidade, Biologia do Solo e Nutrição de Plantas: Consolidando um Paradigma. Caxambu, 1998, p. 432.

3. Oliveira, A.L.M.; Urquiaga, S.; Döbereiner, J.; Baldani, J.I. The effect of inoculating endophytic N2-fixing bacteria on micropropagated sugarcane plants. Plant and Soil. 242(2):205-215, 2002.

4. Polidoro, J.C.. O molibdênio na nutrição nitrogenada e na contribuição da fixação biológica do nitrogênio associada à cultura da cana-de-açúcar. Seropédica, RJ, 2002, 185p. (Tese de Doutorado. UFRRJ).

5. Urquiaga, S.; Cruz, K.H.S.; Boddey, R.M. Contribution of nitrogen fixation to sugarcane: nitrogen-15 and nitrogen balance estimates. Soil Sci. Soc. Am. Proc., 56:105-114, 1992. 